\title{
Cikkismertetés: A cukrozott üdítők adóztatásának társadalmi hatásai
}

\author{
Article review: The social impact of a tax on sugar-sweetened beverages
}

Ismertető: $\quad$ Kaposvári Csilla $₫$

Nemzeti Népegészségügyi Központ

Ismertetett cikk: Backholer K, Sarink D, Beauchamp A, et al: The impact of a tax on sugar-sweetened beverages according to socio-economic position: a systematic review of the evidence. Public Health Nutr. 2016 Dec;19(17):3070-3084. Epub 2016 May 16. doi: $\underline{10.1017 / S 136898001600104 X}$

Beküldve: $\quad$ 2019. 03. 04.

doi: $\quad$ 10.24365/ef.v60i4.436

Kulcsszavak: elhízás; társadalmi-gazdasági egyenlőtlenségek; táplálkozás; cukrozott üdítők

Keywords: obesity; socio-economic inequalities; nutrition; sugar-sweetened beverage

\section{A SZISZTEMATIKUS SZAKIRODALMI ÁTTEKINTÉS CÉLKITÜZÉSE}

A cukros üdítőkre kivetett adókat többek között a lakosság elhízása egyik ellenszereként alkalmazzák, ám az adó hatása a különböző társadalmi-gazdasági helyzetű csoportoknál nem egyértelmű. Jelen áttekintés célja volt, hogy társadalmi-gazdasági helyzet szerint felmérje az adók hatását a cukros üdítők vásárlására és fogyasztására, az elhízásra és a fizetett adó mennyiségére.

\section{A SZISZTEMATIKUS SZAKIRODALMI ÁTTEKINTÉS MÓDSZERTANA ÉS EREDMÉNYEI}

A szisztematikus kutatás egyrészt OVID és EMBASE adatbázisokban történt, valamint magas jövedelmú országok nem tudományos szakirodalmaiban. Az áttekintés célja olyan kutatások azonosítása volt, amelyek vizsgálták, hogy hogyan hat a cukrozott üdítők árának növekedése a vásárlási és fogyasztási hajlandóságra; valamint a különböző társadalmigazdasági helyzetűek körében elemezték az eredményeket, illetve a fizetett adó mértékét. A kiválasztott 11 cikk között három vizsgálati típus volt elkülöníthető: (i) olyan közlemények, amelyek a cukrosüdítő-adó változása és a cukros üdítő fogyasztása és/vagy testsúly közötti összefüggéseket vizsgálták (3 db); (ii) olyan közlemények, amelyek a cukrosüdítő-kereslet árrugalmasságát becsülték (1 db); (iii) hipotetikus cukrosüdítő-adó hatásának modellezése árrugalmassági becslésekkel, társadalmi-gazdasági helyzet szerinti fogyasztással, energiabevitellel vagy testsúllyal kombinálva (7 db). Néhány kutatás szignifikancia tesztet is végzett az egyes társadalmi-gazdasági csoportokban becsült kimenetek különbségei tekintetében. $\mathrm{Az}$ a hét tanulmány, amelyben az adó mértékének növelése után a teljes lakosságnál testsúlyváltozást mértek, vagy hasonló mértékű testsúlycsökkenést jeleztek az összes társadalmi-gazdasági csoportban, 
vagy nagyobb mértékű testsúlycsökkenést jeleztek az alacsonyabb társadalmi-gazdasági csoportokban a magasabb helyzetben lévőkhöz képest. Mind az 5 tanulmány, amely vizsgálta a háztartások által fizetett adót arról számolt be, hogy a cukros üdítő adója regresszív hatású, de kicsi a különbség az alacsony és a magas jövedelmú háztartások között (a háztartás éves jövedelmének 0,10-1,0\%-át fizették cukrosüdítő-adóban az alacsony jövedelmü, míg 0,03\%-0,60\%-át a magas jövedelmű háztartásokban).

\section{KÖVETKEZTETÉSEK}

A rendelkezésre álló bizonyítékok alapján elmondható, hogy a cukros üdítőkre kivetett adók vagy hasonló mértékű egészségnyereséget eredményeznek az egyes társadalmi-gazdasági rétegekben, vagy nagyobb nyereséget hoznak az alacsonyabb társadalmi-gazdasági helyzetű csoportokban. A cukros üdítőkre kivetett adók pénzügyileg regresszív hatásúak, azaz arányaiban csak kis mértékben, de jobban sújtják a szegényebb rétegeket.

\section{TANULSÁGOK HAZAI SZAKEMBEREK SZÁMÁRA}

A cukros üdítőkre kivetett adók alkalmazása során az adó különböző hatásainak mérésére megfelelő egészségmonitorozási és értékelési vizsgálatokra van szükség, ahol együtt követhető a társadalmigazdasági helyzet szerint a fogyasztásváltozás és a különböző egészségkimenetek, valamint a háztartások által fizetett adóterhek. 